\title{
FLOWERING PERCENTAGE IN ARABICA COFFEE CROPS DEPENDS ON THE WATER DEFICIT LEVEL APPLIED DURING THE PRE-FLOWERING STAGE ${ }^{1}$
}

\author{
CLÁUDIO PAGOTTO RONCHI ${ }^{2 *}$, FELIPE RODRIGUES MIRANDA ${ }^{2}$
}

\begin{abstract}
Nonuniform flowering leads to uneven ripening of fruits, which impairs harvesting efficiency and the quality of the coffee. The aim of this study was to determine the water deficit level required to break flower bud dormancy of Coffea arabica and to evaluate its effects on gas exchange, photosynthetic pigment levels, coffee yield, and fruit maturation. After a growth period of 18 months in $200 \mathrm{~L}$ pots maintained under greenhouse conditions, water deficit treatments were imposed by withholding watering from plants exhibiting at least a $60 \%$ rate of "E4 stage" flower buds. When five groups of six coffee plants reached the pre-dawn leaf water potential $\left(\Psi_{\mathrm{w}_{\mathrm{pd}}}\right)$ of $-0.04,-0.65,-1.43,-1.96$, and $-2.82 \mathrm{MPa}$, the leaf gas exchange was measured and leaf disks were collected to quantify the photosynthetic pigment levels, after which, watering was resumed. The rate of opened flowers increased with the reduction of $\Psi_{\text {pd }}$ based on the mathematical model, $\mathrm{Y}=67.064+$ $20.660 \times \ln \left(-\Psi_{\mathrm{w}_{\mathrm{pd}}}\right)$. The leaf gas exchange was strongly affected by water deficit levels, without any alterations in the photosynthetic pigment levels. Coffee yield was not affected by the treatments but the ripe stages of cherries increased slightly with the reduction in $\Psi_{\mathrm{w}_{\mathrm{pd}}}$. The water deficit level applied at the pre-flowering stage determined the percentage of flowering in C. arabica.
\end{abstract}

Keywords: Coffea arabica. Flowering. Watering. Gas exchange.

\section{A INTENSIDADE DA FLORADA DO CAFÉ ARÁBICA DEPENDE DO NÍVEL DE DEFICIT HÍDRICO APLICADO NO PERÍODO PRÉ-FLORADA}

\begin{abstract}
RESUMO - Floradas desuniformes traduzem-se em desigualdade na maturação dos frutos, comprometendo a eficiência de colheita e a qualidade do café. Objetivou-se neste trabalho determinar o nível de deficit hídrico para a quebra de dormência das gemas de Coffea arabica, e seus efeitos sobre as trocas gasosas, os teores de pigmentos fotossintéticos, a produtividade e a uniformidade de maturação dos frutos. Após 18 meses de cultivo em vasos de $200 \mathrm{~L}$, em casa de vegetação, suspendeu-se a irrigação, em plantas que apresentavam no mínimo $60 \%$ dos botões florais no estádio E4. Após cinco grupos de seis plantas cada atingirem os potenciais hídricos foliares de antemanhã $\left(\Psi \mathrm{w}_{\mathrm{pd}}\right)$ iguais a $-0,04,-0,65,-1,43,-1,96$ e -2,82 $\mathrm{MPa}$, mediram-se as trocas gasosas do cafeeiro e coletaram-se discos foliares para quantificação de pigmentos, retornando-se, em seguida, a irrigação. A porcentagem de flores (ou intensidade da florada) aumentou com a redução do $\Psi_{\mathrm{W}_{\mathrm{pd}}}$ segundo o modelo $Y=67,064+20,660 * \ln \left(-\Psi_{\mathrm{w}_{\mathrm{pd}}}\right)$. As trocas gasosas do cafeeiro foram fortemente afetadas pelos níveis de deficit hídrico, sem, contudo, verificarem-se reduções nos teores de pigmentos fotossintéticos. A produtividade do cafeeiro não foi afetada, mas a porcentagem de grãos cereja foi ligeiramente maior sob deficits mais severos. O nível de deficit hídrico aplicado no período pré-florada determinou sua intensidade em café arábica.
\end{abstract}

Palavras-chave: Coffea arabica. Floração. Irrigação. Trocas gasosas.

\footnotetext{
*Corresponding author

${ }^{1}$ Received for publication in 08/07/2019; accepted in 12/26/2019.

Paper extracted from a project supported by Fundação de Amparo à Pesquisa do Estado de Minas Gerais (CAG-APQ-00328-09).

${ }^{2}$ Universidade Federal de Viçosa, Florestal, MG, Brazil; claudiopagotto@ufv.br - ORCID: 0000-0003-4333-0846, felipe.r.miranda@ufv.br - ORCID: 0000-0001-5599-3482.
} 


\section{INTRODUCTION}

The Cerrado Mineiro region will produce between 4.8 and 5.0 million $60 \mathrm{~kg}$ bags of arabica coffee in 2019 , which corresponds to $18.5 \%$ of the production of the state and $13.24 \%$ of the national production (BRASIL, 2019). Besides mechanization (ORTEGA; JESUS, 2011), this region adopts watering procedures to ensure high yields (SILVA; TEODORO; MELO, 2008; CAMARGO, 2010; FERNANDES et al., 2012; 2016; LEITE JÚNIOR; FARIA, 2016; MATIELLO et al., 2016; SAKAI et al., 2015). Aparecido and Rolim (2018) recently showed that a water deficit affected both the reproductive and vegetative phases of the crop coffee in the Cerrado Mineiro region, which reinforces the importance of correct watering of the coffee crop in this region.

Although watering just before flowering can induce the uneven development of flower buds (DaMATTA et al., 2007; SILVA et al., 2009; RONCHI et al., 2015), many coffee crops are watered without interruption. Together with sporadic rains near spring, this leads to irregular flowering events and, consequently, uneven ripening of fruits (DaMATTA et al., 2007; RONCHI et al., 2015), with negative effects on production costs and quality of the grains (DaMATTA et al., 2007).

To concentrate the flower bud opening and minimize these problems, a water deficit has been applied during the winter, which is necessary to break the dormancy of buds, and watering after this period causes anthesis (flower opening) (ALVIM, 1960; MAGALHÃES; ANGELOCCI, 1976; CRISOSTO; GRANTZ; MEINZER, 1992; MASARIRAMBI; CHINGWARA; SHONGWE, 2009; SILVA et al., 2009; QUIÑONES et al., 2011). However, there is no consensus on the most relevant criteria for the application of such a water deficit. Establishing fixed dates to suspend and resume watering, without monitoring the level of water deficit and stage of flwer buds, as proposed by Guerra, Rocha, and Rodrigues (2005), is the most empirical way to apply the water deficit. Several factors alter the rate of progress of the water deficit and, consequently, the time required to reach the adequate deficit level (DaMATTA et al., 2007; SILVA et al., 2009). Thus, establishing fixed dates as a criterion can induce severe water deficiencies in plants (MERA et al., 2011), with irreparable losses in productivity (MERA et al., 2011; FERNANDES et al., 2016; GONZÁLEZ-ROBAINA; CISNEROSZAYAS; MONTILLA, 2017), growth (MERA et al., 2011; SAKAI et al., 2015), and crop longevity.

There is a consensus that a water deficit should be applied when flower buds are physiologically mature, corresponding to the E4 stage (ripe-to-flower stage) (CRISOSTO; GRANTZ; MEINZER, 1992; RENA; BARROS, 2004; SOARES et al., 2005; RONCHI et al., 2015). If applied to the prior stages, even a pre-dawn leaf water potential $\left(\Psi_{\mathrm{w}_{\mathrm{pd}}}\right)$ as low as $-1.90 \mathrm{MPa}$ probably will not have a positive effect on flower bud opening (SOARES et al., 2005). Therefore, there may be an interaction between the stage of development of the flower bud and the level of water deficit in flowering percentage, and both are associated with climatic conditions (SOARES et al., 2005; RONCHI et al., 2015).

We hypothesized that if the coffee crop has a high percentage of buds during the E4 stage, then the dormancy of the flower buds will be broken by subjecting the coffee plant to a minimum level of water deficit, as measured by $\Psi_{\mathrm{w}_{\mathrm{pd}}}$. This threshold for $\Psi \mathrm{w}_{\mathrm{pd}}$ would determine the best time for rewatering and, consequently, improve the percentage of flowering, with minimal negative effects on coffee yield or growth. Thus, the objective of the present study was to define the $\Psi_{\mathrm{w}_{\mathrm{pd}}}$ value required to break the flower bud dormancy (or to promote anthesis) and its effects on the physiological and productive traits of coffee.

\section{MATERIAL AND METHODS}

The experiment was conducted in a greenhouse covered with $100 \mu \mathrm{m}$ clear polyethylene film, with wire mesh on the sides to allow free gas exchange with the external atmosphere. During April 2010, seedlings of Coffea arabica 'Catuaí Vermelho' IAC 144, with eight pairs of leaves, were transplanted into plastic pots with a capacity of 200 L of substrate (soil, sand, and cattle manure mix, $3: 1: 1, \mathrm{v} / \mathrm{v} / \mathrm{v})$. The soil used was a dystrophic redyellow latosol, with clayey texture (67\% clay) and with the following chemical properties: $\mathrm{pH}, 6.02$; organic matter content, $28.1 \mathrm{~g} \mathrm{~kg}^{-1}$; V\%, 30.8; $\mathrm{m} \%$, $0.0 ; \mathrm{P}, 1.8 \mathrm{mg} \mathrm{dm}^{-3} ; \mathrm{K}, 12 \mathrm{mg} \mathrm{dm}^{-3}$; $\mathrm{Ca}, 0.97 \mathrm{cmol}_{\mathrm{c}}$ $\mathrm{dm}^{-3} ; \mathrm{Mg}, 0.29 \mathrm{cmol}_{\mathrm{c}} \mathrm{dm}^{-3}$, t, $1.29 \mathrm{cmol}_{\mathrm{c}} \mathrm{dm}^{-3}$; and $\mathrm{T}$, $4.19 \mathrm{cmol}_{\mathrm{c}} \mathrm{dm}^{-3}$. We used a total of 50 experimental units with each pot received one plant. The bottom and entire lower lateral perimeter of the pots were drilled, and a $5.0 \mathrm{~cm}$ gravel layer was placed at the bottom of each pot to facilitate drainage. During the 18 months after transplantation (MAT), the plants were watered to maintain the field capacity and fertilized via soil and leaf; pest and disease was applied when required.

From August 2011, preliminary counts were made every 2 weeks to monitor the mean percentage of the different stages of the development of the flower buds on plagiotropic branches randomly distributed in the middle third of the 50 coffee plants. The flower bud developmental stages were classified according to Camayo-Vélez and Arcila-Pulgarín (1996) as E2, undifferentiated flower buds; E3, physiologically immature flower bud - in this stage, flower buds are already greater than node stipules, and even though they can be easily counted, they are 
not yet completely individualized at the glomerule inflorescence; E4, physiologically mature flower bud (ripe-to-flower stage) - the individual flower bud are green and completely discernible at each glomerule, and they remain in this state until an external stimulus brings about a renewal of growth; E5, after the breack of dormancy, just before anthesis, when the buds appear completely white; and E6, anthesis (opened flowers). For the purpose of this study, the flower bud stages E5 and E6 have been combined.

The water deficit treatments were only administered once the minimum percentage of E4 had reached $60 \%$ in all coffee plants, which occurred in early September. Then, four plagiotropic branches with a higher apparent abundance of buds in the middle third of each of the 50 plants were marked and all flower bud stages were counted. The mean percentage of each flower bud stage was then estimated. This count was performed again 12 days after rewatering the coffee plants, to estimate the percentage of open flowers as a function of the treatments.

A randomized block design with five treatments and six replicates was used. The treatments consisted of subjecting groups of plants to five $\Psi_{\mathrm{w}_{\mathrm{pd}}}$ : $-0.03,-0.70,-1.40,-2.10$, and $-2.80 \mathrm{MPa}$. Watering was suspended in 44 pots, and six retained continuous watering, which was the control treatment $(-0.03 \mathrm{MPa})$. From this day, $\Psi_{\mathrm{w}_{\mathrm{pd}}}$ was measured daily in all plants, with a pressure pump (Scholander pump), before dawn. When a group of six plants reached, on average, a $\Psi_{\mathrm{w}_{\mathrm{pd}}}$ value close to the target for the treatment (i.e., $-0.70,-1.40,-2.10$, and $-2.08 \mathrm{MPa}$ ), they constituted the six replicates for the treatment. On the same day, the additional measurements (described below) were conducted, and then full watering of the group of plants was resumed, to evaluate the effect of rehydration on flowering. From this phase until the next year's harvest, the plants were watered daily. Of the 50 plants, only 30 were effectively used in the experiment.

On the same day that the group of plants attained the desired water deficit level, instantaneous gas exchange measurements were performed in these groups of plants and in the control treatment $\left(\Psi_{\mathrm{w}_{\mathrm{pd}}}=\right.$ $-0.03 \mathrm{MPa}$ ). Evaluations were performed at 08:00, 11:30, and 15:00 h on fully developed leaves from the third pair from the apex of the same plagiotropic branches identified to count the flower bud stages. A total of 12 leaves/treatment (two leaves per plant) were evaluated. Stomatal conductance $\left(g_{\mathrm{s}}\right)$, net $\mathrm{CO}_{2}$ assimilation rate $(A)$, transpiration rate $(E)$, instantaneous water use efficiency $(A / E)$, ratio of internal and external $\mathrm{CO}_{2}$ concentrations $\left(C_{\mathrm{i}} / C_{\mathrm{a}}\right)$, and the vapor pressure deficit between the interior of the leaf and the atmosphere $(D P V)$ were measured in the open system under saturated artificial light $(900 \mu$ mol photons $\mathrm{m}^{-2} \mathrm{~s}^{-1}$ ) and ambient $\mathrm{CO}_{2}$ concentration, with a portable infrared gas analyzer (LICOR
6400XT, Li-COR, Lincoln, USA).

From the same pair of leaves used to evaluate the gas exchange, leaf discs containing approximately $0.160 \mathrm{~g}$ of fresh tissue were collected at $12: 00 \mathrm{~h}$ and these samples were immediately frozen in liquid nitrogen for further quantification of leaf levels of photosynthetic pigments (chlorophyll $a$ and $b$, total chlorophylls, and total carotenoids). The pigments were extracted in $80 \%(\mathrm{v} / \mathrm{v})$ acetone/water and determined according to the method described by Ronchi et al. (2006).

In June 2012, the six plants from each treatment were harvested by manual stripping (full harvest), followed by measuring the coffee fruit production per plant. Then, the percentage of each ripening stages of coffee fruits (unripe, yellow cherry, ripe cherry and dried cherry) were measured in $0.5 \mathrm{~L}$ samples, following the methodology described by Ronchi et al. (2015). Then, the fruit maturation classes unripe+yellow cherry and ripe+dried cherries were combined for data discussion.

All data were submitted to analysis of variance by the $F$ tes using the Statistical and Genetic Analysis System (SAEG, 2004). Regression equations were adjusted by relating the variables to $\Psi_{\mathrm{W}_{\mathrm{pd}}}$. The models were chosen based on biological logic, the significance of the regression coefficients, and $\mathrm{R}^{2}$ values. Gas exchange data were analyzed separately by measurement time.

\section{RESULTS AND DISCUSSION}

Several studies have suggested that the stage of development of flower buds called E4 is when the buds are physiologically mature and the most sensitive to water deficit to break dormancy (ALVIM, 1960; CRISOSTO; GRANTZ; MEINZER, 1992; RENA; BARROS, 2004; SOARES et al., 2005; SILVA et al., 2009). Given that one of the objectives of the present study was to determine the minimum level of water deficit necessary to break the dormancy of flower buds, watering was suspended (or a deficit was applied) when the percentage of E4 reached $60 \%$. At 18 MAT (early September), the 30 plants used in this experiment had, on average, $6 \%$ of buds in E2 stage, $32 \%$ in E3 stage, and $62 \%$ in the maturing E4 stage; thus, watering was suspended on the following day.

Even when cultivated in large volume pots (200 L), the adverse climatic conditions observed in the days following the suspension of watering (maximum temperatures of $30.5{ }^{\circ} \mathrm{C}$, relative air humidity of $19.0 \%$, and $D P V$ of $3.97 \mathrm{kPa}$ ) induced a rapid rate of water deficit imposition. Accordingly, after 4 days of watering suspension, two groups of six plants each had a mean $\Psi_{\mathrm{w}_{\mathrm{pd}}}$ of -0.65 and -1.43 $\mathrm{MPa}$ (Table 1); and 6 days after the watering suspension, two groups of six plants had reached the 
most severe water deficit levels, represented by a $\Psi \mathrm{W}_{\mathrm{pd}}$ of -1.96 and $-2.82 \mathrm{MPa}$ (Table 1). The group of irrigated plants had, at these times, a mean $\Psi_{\mathrm{w}_{\mathrm{pd}}}$ of $0.04 \mathrm{MPa}$. Thus, five levels of water deficit were established, with values very close to the preestablished levels (Table 1).

We also highlight some other findings even before associating water deficit levels with the flowering percentage, because these findings demonstrate that individual plants or groups of plants are supposedly similar in all aspects, i.e., grown in pots of equal substrate volume and under the same management conditions during $18 \mathrm{MAT}$, and after suspended watering caused dehydration at different rates, resulting in different water deficit level safter a similar period (4 or 6 days; Table 1). Ronchi et al., (2015) also reported different water deficit levels among arabica coffee cultivars in the field after an equal period of suspended water ingunder similar climatic conditions.

Table 1. Expected and registered pre-dawn leaf water potential $\left(\Psi_{\mathrm{w}_{\mathrm{pd}}}\right)$, and time to achieve the expected water deficit level in coffee plants cultivated in $200 \mathrm{~L}$ pots.

\begin{tabular}{lcc}
\hline $\begin{array}{l}\Psi_{\mathrm{pd}} \\
\text { Expected (-MPa) }\end{array}$ & $\begin{array}{c}\Psi_{\mathrm{w}_{\mathrm{pd}}} \text { registered } \\
(-\mathrm{MPa})\end{array}$ & $\begin{array}{c}\text { Time to attain the desired deficit level } \\
\text { (days) }\end{array}$ \\
\hline 0.03 & $0.04 \pm 0.001$ & - \\
0.70 & $0.65 \pm 0.016$ & 4 \\
1.40 & $1.43 \pm 0.008$ & 4 \\
2.10 & $1.96 \pm 0.022$ & 6 \\
2.80 & $2.82 \pm 0.025$ & 6 \\
\hline
\end{tabular}

Different water deficit rates, under controlled conditions, are expected between different genetic material (species or cultivars) (VINASCO; BUILES; GUERRERO, 2016), with different degrees of tolerance to drought, or even in the same genotype but grown in pots of different sizes (RONCHI et al., 2006) or under different climatic and growth conditions (DaMATTA et al. 2007). Therefore, if in the supposedly homogeneous conditions (i.e., soil, climate, and management) of this experiment such differences occurred, then it would be inconsistent to suggest fixed dates for suspending and resuming watering among coffee crops as proposed by Guerra, Rocha and Rodrigues (2005), even considering the practical aspect of management (DaMATTA et al., 2007). Therefore, the water deficit level of coffee plants is the major factor in deciding to use this methodology.

All drought treatments induced some degree of anthesis after watering of the coffee plants. The percentage of flowering increased curvilinearly (logarithmic model) with the reduction in $\Psi \mathrm{w}_{\mathrm{pd}}$ (Figure 1). Therefore, a $\Psi_{\mathrm{w}_{\mathrm{pd}}}$ of $-0.71,-1.15$, and $1.87 \mathrm{MPa}$ was needed to induce $60 \%, 70 \%$, and $80 \%$ opening, respectively, of the flower buds. The published water potential $(\Psi)$ in plants under deficit, not necessarily $\Psi_{\mathrm{W}_{\mathrm{pd}}}$, required for breaking the dormancy of flower buds are variable, e.g., -0.80 MPa (CRISOSTO; GRANTZ; MEINZER, 1992), 1.1 to $1.2 \mathrm{MPa}$ (MAGALHÃES; ANGELOCI, 1976; SILVA et al., 2009), -1.7 MPa (SILVA et al., 2009), -2.0 MPa (GUERRA; ROCHA; RODRIGUES, 2005), and -2.65 MPa (SCHUCH; FUCHIGAMI;
NAGAO, 1992).

Thus, moderate deficits $\left(\Psi_{\mathrm{w}_{\mathrm{pd}}}\right.$ of approximately $-1.15 \mathrm{MPa}$ ) are adequate to cause a high percentage of anthesis in flower buds, and the increments in anthesis decreased with an increase of the water deficit level from -1.5 to $-1.8 \mathrm{MPa}$ (Figure 1). Therefore, it is unnecessary to submit the coffee crop to severe water deficits, with $\Psi_{\mathrm{w}_{\mathrm{pd}}}$ below -1.8 MPa (GUERRA; ROCHA; RODRIGUES, 2005), exposing the crop to the risk of yield losses in the following year (GUERRA; ROCHA; RODRIGUES, 2005; SILVA; TEODORO; MELO, 2008; SILVA et al., 2009; MERA et al., 2011; GONZÁLEZROBAINA; CISNEROS-ZAYAS; MONTILLA, 2017), given the various negative physiological effects of water deficit on coffee plants (DaMATTA; RAMALHO, 2006; DaMATTA et al., 2007).

Contrary to the hypothesis that water deficit caused dormancy of flower buds, Alvim (1960) reported that a water deficit was reqjuired to break the true dormancy of flower buds, which was confirmed by subsequent studies (MAGALHÃES; ANGELOCCI, 1976; CRISOSTO; GRANTZ; MEINZER, 1992; SILVA et al., 2009) and now by our results. In addition, the effectiveness of the water deficit in breaking dormancy was only valid for buds in the E4 stage (CRISOSTO; GRANTZ; MEINZER, 1992; RENA; BARROS, 2004; SOARES et al., 2005). For example, an increase in flowering did not occur even in coffee plants subjected to $\Psi_{\mathrm{w}_{\mathrm{pd}}}$ as low as $-1.90 \mathrm{MPa}$, because such a deficit was applied to stages before the E4 stage, which are not susceptible to the water deficit (SOARES et al., 2005). 


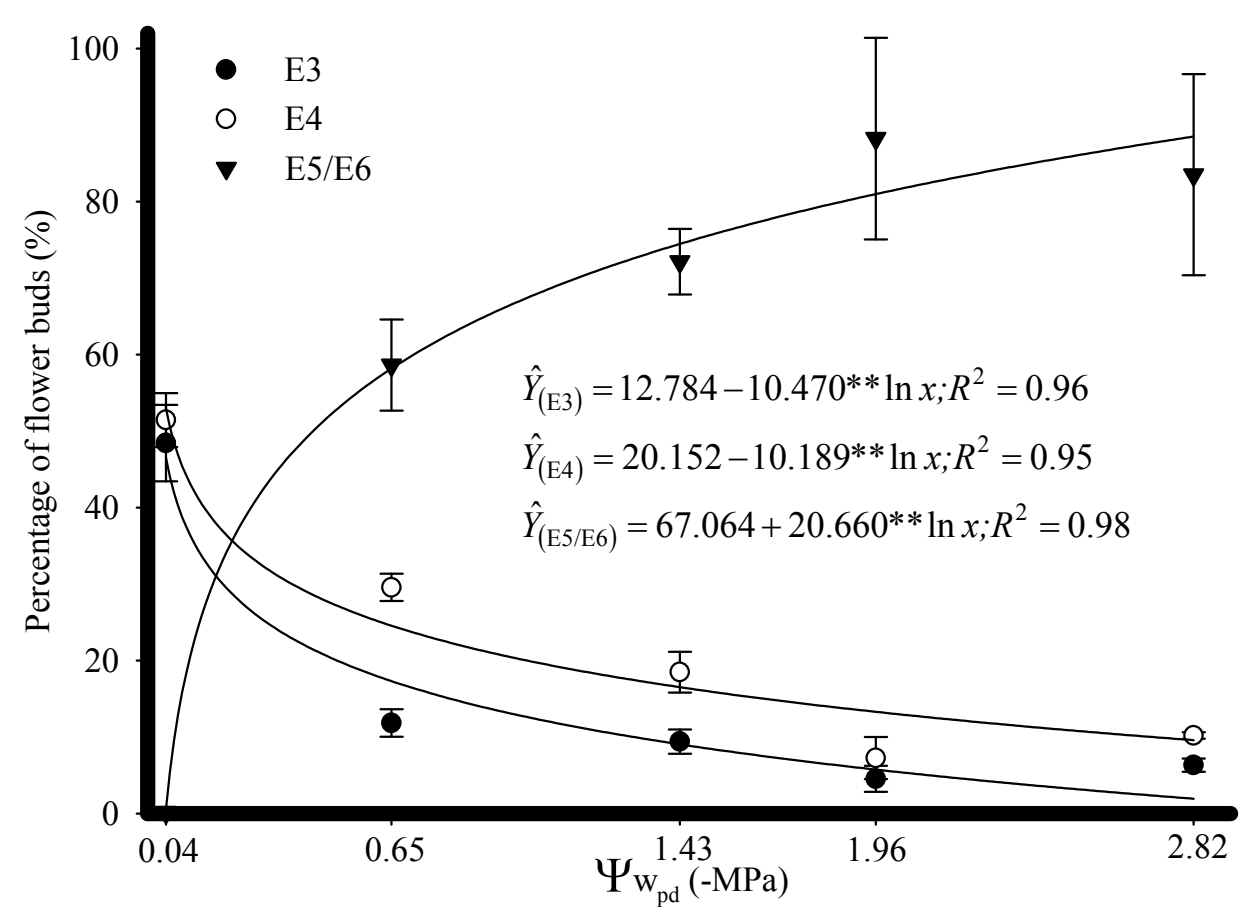

Figure 1. Percentage of the different stages of development of flower buds (E3, E4, and E5/E6), 12 days after resumingwatering, as a function of the pre-dawn leaf water potential ( $\Psi_{\mathrm{wpd}_{\mathrm{pd}}}$ ). Each point represents the mean \pm standard error; $n=6$. $* *$ significant at $1 \%$ by the $t$-test. The $\Psi \mathrm{w}_{\mathrm{pd}}$ value was multiplied by (-1) to adjust the equations. E3, immature flower bud; E4, ripe-to-flower stage; E5/E6, opened flowers.

Our results suggest that a high percentage of buds in the E4 stage is, in fact, necessary for implementation of the deficit, but they also allow us to state that the greater the water deficit, the more effective the breaking of the dormancy of the flower buds. This occurs especially for flower buds in the E4 stage, and also for some buds in the E3 stage (likely those more advanced physiologically but have not yet reached the E4 stage). Figure 1 shows that the percentage of the remaining E3 and E4 stage buds in coffee plants decreased significantly and curvilinearly $(P<0.01)$ with the reduction of $\Psi \mathrm{w}_{\mathrm{pd}}$. For example, the remaining percentage of buds in the E3 and E4 stages after the application of $\Psi_{\mathrm{w}_{\mathrm{pd}}}$ of $0.71,-1.87$, and $-2.82 \mathrm{MPa}$ were, $16.4 \%$ and $23.6 \%$, $6.2 \%$ and $13.8 \%$, and $1.9 \%$ and $9.5 \%$, respectively. Therefore, more severe water deficits are responsible for a greater percentage of flowering, although these water deficits should not necessarily be applied because they affect the gas exchange of the coffee crop (Figure 2), among other adverse physiological effects.

The rates of net $\mathrm{CO}_{2}$ assimilation $(A)$ declined curvilinearly with the reduction in $\Psi_{\mathrm{w}_{\mathrm{pd}}}$ during the three measurement periods (Figure 2A) with striking effects even with moderate water deficits. This is a common response in plants, although a diversity of factors interferes with the relationship between $A$ and $\Psi \mathrm{w}_{\mathrm{pd}}$ (TAIZ et al., 2017). $\Psi \mathrm{w}_{\mathrm{pd}}$ as low as $-1.0 \mathrm{MPa}$ or $-1.5 \mathrm{MPa}$ has been shown to be insufficient to cause a decrease in $A$ in the coffee crop (DaMATTA; RAMALHO, 2006). The reduction in $A$, especially under moderate deficits, occurred with a proportional reduction in $g_{\mathrm{s}}$ (Figure $2 \mathrm{~B}$ ), and a progressive decrease of $\Psi \mathrm{w}_{\mathrm{pd}}$ was noted by Peloso et al. (2017). Stomata closure is routinely considered a primary indicator of water deficiency (OLIVEIRA; OLIVEIRA; CASTRO, 2009) and is a mechanism that prevents excessive water loss (VINASCO; BUILES; GUERRERO, 2016) because of the increase in the $D P V$, with maximum values of $g_{\mathrm{s}}$ occurring at $D P V$ close to $2 \mathrm{kPa}$ (MELKE; FETENE, 2014). With a reduction in $g s$, a decrease in $E$ was observed (Figure 2C). In addition, because there were proportional reductions in $A$ and $E$ as the water deficit increased, there was no significant change in the instantaneous water use efficiency, estimated by the $A / E$ ratio (Figure 2D).

In addition to the stomatal limitations described above, at more severe deficits, $A$ (Figure $2 \mathrm{~A}$ ) and $g_{\mathrm{s}}$ (Figure $2 \mathrm{~B}$ ) remained extremely low, but with a significant increase in the $C_{i} / C_{a}$ ratio (Figure $2 \mathrm{E}$ ), indicating that non-stomatal limitations were also responsible for the low photosynthetic rates (RONCHI et al., 2006). Moreover, the variation in $A$ was not related to the levels of photosynthetic pigments in the leaves because they were not influenced by the deficit levels (Figure 3), probably because of the short length of the deficit (only 4 to 6 days). 

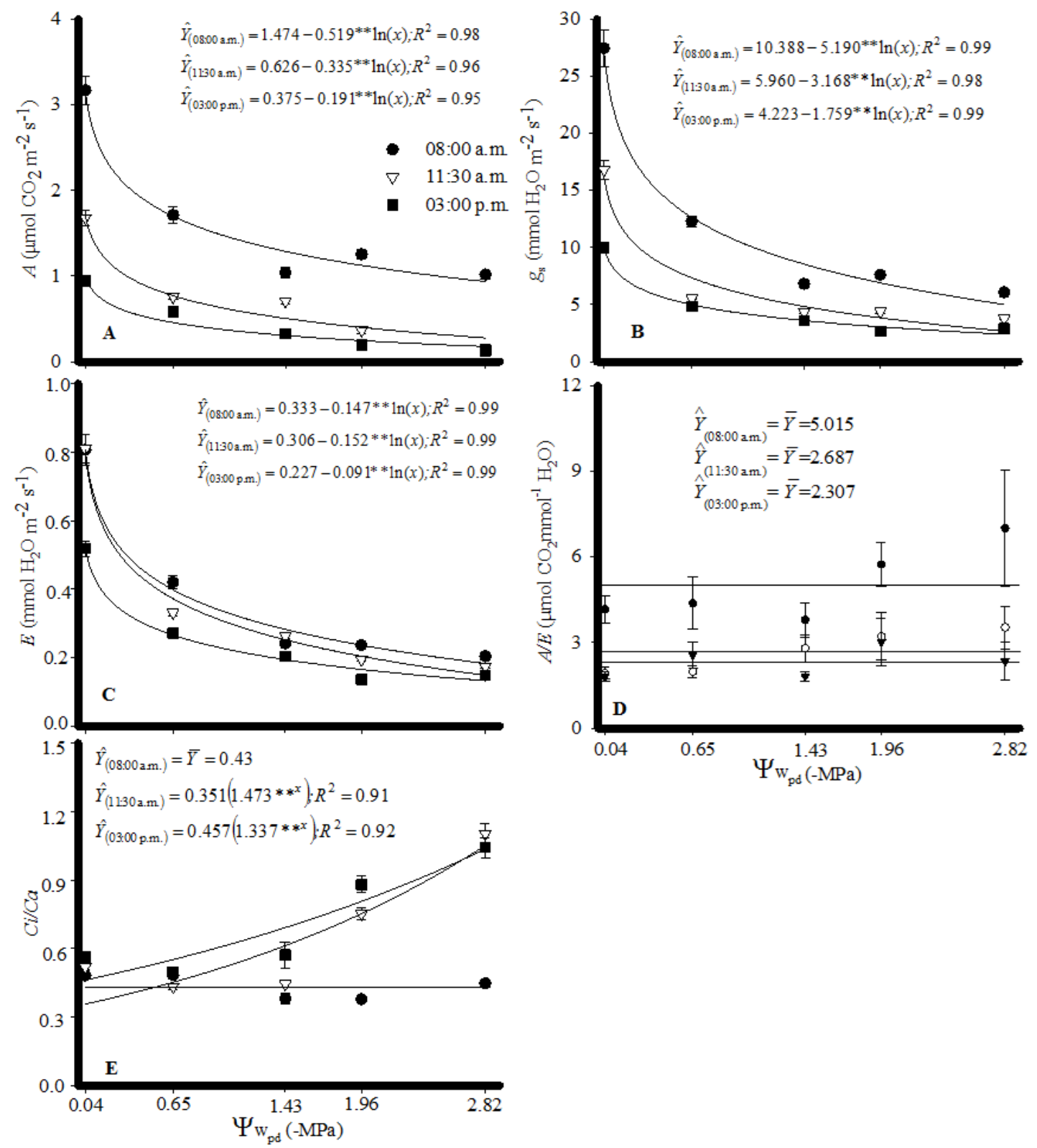

Figure 2. Net carbon assimilation rate, $A(\mathrm{~A})$; stomatal conductance, $g_{\mathrm{s}}(\mathrm{B})$; transpiration rate, $E(\mathrm{C})$; instantaneous water use efficiency, $A / E(\mathrm{D})$; and relationship between internal/external $\mathrm{CO}_{2}$ concentration, $C_{\mathrm{i}} / C_{\mathrm{a}}(\mathrm{E})$ in the leaves of arabica coffee plants based on the pre-dawn leaf water potential $\left(\Psi_{\mathrm{w}_{\mathrm{pd}}}\right)$ (immediately before the resumingwatering), evaluated at three times in the day (mean \pm standard deviation; $n=12$ ). The $\Psi_{\mathrm{w}_{\mathrm{pd}}}-0.04 \mathrm{MPa}$ represents the irrigation treatment.

The maximum values observed in $A$ were low, even in the irrigation treatment, at 08:00 pm $\left(\sim 3.0 \mu \mathrm{mol} \mathrm{m} \mathrm{m}^{-2} \mathrm{~s}^{-1}\right.$; Figure $\left.2 \mathrm{~A}\right)$; however, these are normal values for the species under various conditions of coffee cultivation (SILVA et al., 2004). These low values $(75 \%$ lower than the levels recorded for the species) might be a direct reflection of the retro-inhibition of photosynthesis because of the cultivation of plants in pots over a long period (RONCHI et al., 2006), as in this experiment.

The different water deficit levels did not significantly influence $(F$ test; $P>0.05)$ coffee tree production (Figure 4A), probably because of the short period (4 to 6 days) of exposure to the water deficit, even to those showing $\Psi_{\mathrm{w}_{\mathrm{pd}}}$ as low as -2.82
MPa. In the field, in the Cerrado Mineiro region, even though with a greater period of water deficit, a higher loss of coffee yield would be expected (FERNANDES et al., 2016; APARECIDO; ROLIM, 2018), Ronchi et al. (2015) did not find any coffee yield reduction as a function of a long period of withholding watering. In this case, it occurred due to a mild water deficit observed at the end of the drought period. In fact, a mild $(80 \%$ of the full watering amount), but not a moderate or severe $(40 \%$ and $60 \%$ of the full watering amount, respectively) water deficit did not affect coffee yield in China when it was associated with proper shading (LIU et al., 2018).

The percentage of ripe cherries increased and 


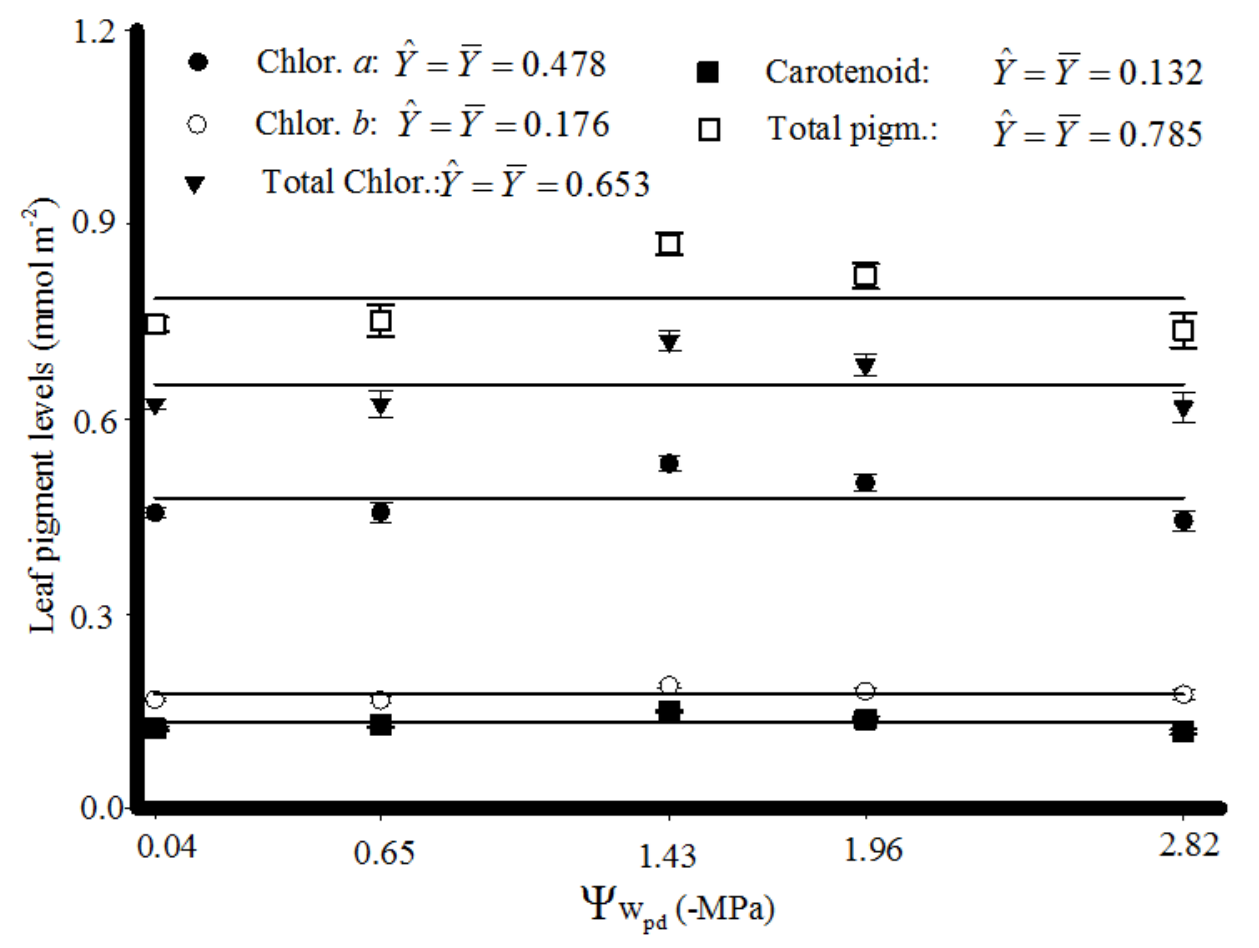

Figure 3. Leaf chlorophyll $a$ (Chlor. $a$ ), chlorophyll $b$ (Chlor. $b$ ), total chlorophyll (Total Chlor.), carotenoid, and total pigments (Total pigm.) in leaves of coffee plants based on the pre-dawn leaf water potential $\left(\Psi_{\mathrm{w}_{\mathrm{pd}}}\right)$. The figures refer to the mean \pm standard error, $n=6$. $(F$ test; $P>0.05)$.

unripe fruit decreased linearly with an increase in the deficit level (Figure 4B). The high percentage of ripe fruits is desirable because this is the proper stage of fruit to ensure the high quality of the beverage (MESQUITA et al., 2016). Fruit harvested before the ideal period produces a lower quality beverage (FAGAN et al., 2011) and does not add value to the product (GIOMO; BORÉM, 2011). These results are partly consistent with the flowering percentage obtained in the present study, indicating the importance of a water deficit applied during preflowering for the standardization of the maturation of coffee fruit (SILVA et al., 2009). Souza et al. (2014) also observed that a water deficit applied at the preflowering stage significantly increased the percentage of ripe cherries for six of the nine clones of conilon coffee that were tested compared to the continuously watered treatment.

These results suggest that the loss of productivity observed in some studies may have been caused by the reduction in global carbon fixation by the plant, in plants subjected to very severe water deficits $\left(\Psi \mathrm{w}_{\mathrm{pd}}<-2.0 \mathrm{MPa}\right)$ for a long period (GUERRA; ROCHA; RODRIGUES, 2005; MERA et al., 2011; SILVA et al., 2009). In contrast to our observations, the progression of the deficit in the field is usually slow. Therefore, significant reductions in growth and productivity can occur with a slight loss in the assimilation of carbon, except over the long-term. In the field, one must consider the characteristics of the crop, and the climatic conditions of each microregion, which will change the time required to reach water deficit levels that are adequate for inducing anthesis. A minimum water deficit $\left(\Psi_{\mathrm{w}_{\mathrm{pd}}} \leq-0.71 \mathrm{MPa}\right)$, applied during preflowering, in irrigated crops and with a high percentage of E4 stage buds, can provide better results for the producer, especially in regions where this deficit level can be quickly reached. 


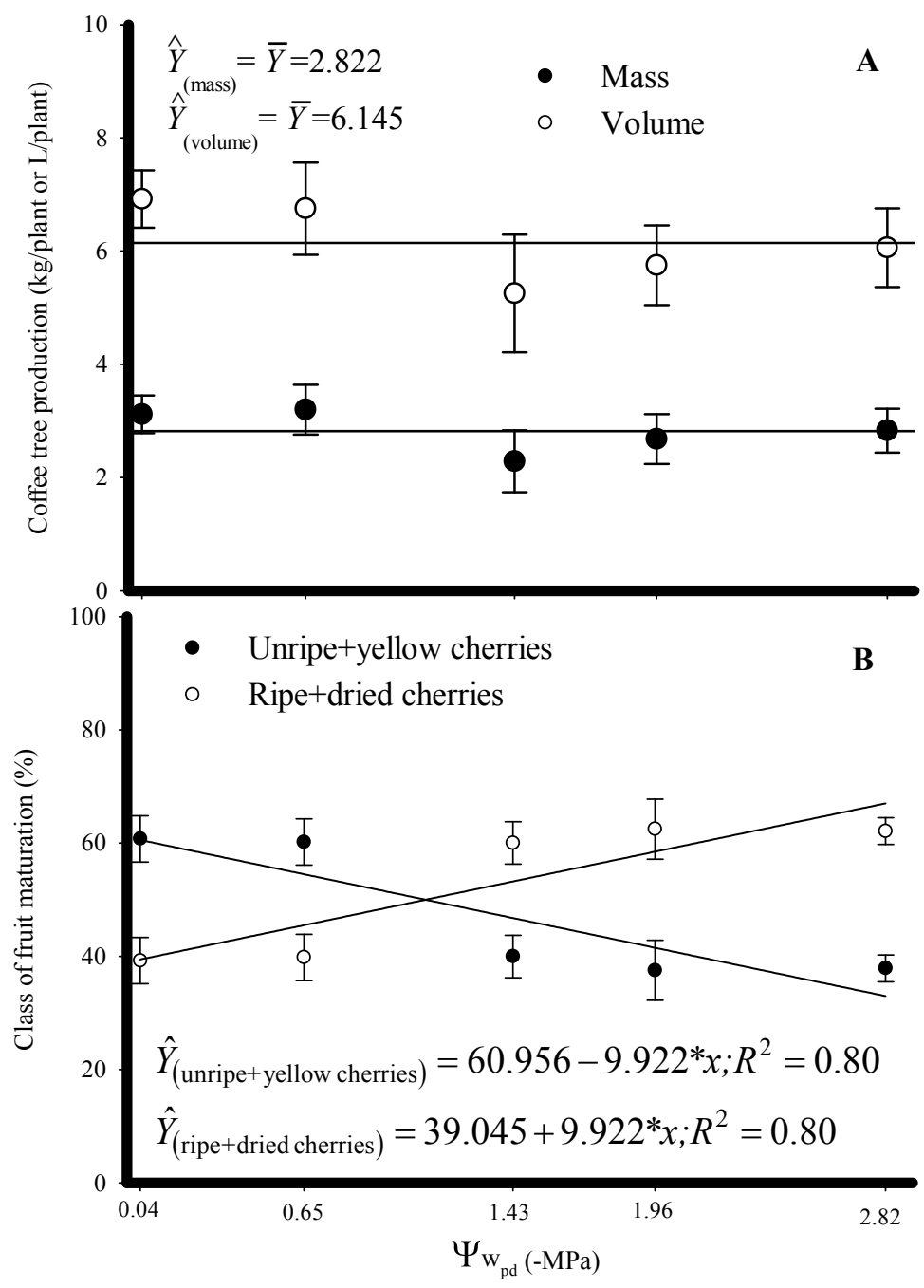

Figure 4. Coffee tree production (A) and percentage of the distribution of newly harvested fruits in two classes of maturation "unripe+yellow cherries" and "ripe+dried cherries" (B) based on the pre-dawn leaf water potential ( $\left.\Psi \mathrm{w}_{\mathrm{pd}}\right)$. The dispersion represents the mean \pm standard error, $n=6$. * Significant at $5 \%$ by the $t$ test. To adjust the equations, the value of $\Psi \mathrm{w}_{\mathrm{pd}}$ was multiplied by (-1).

\section{CONCLUSIONS}

Under greenhouse conditions, water deficit level determined the intensity of flowering. A maximum leaf $\Psi_{\mathrm{w}_{\mathrm{pd}}}$ of $-1.15 \mathrm{MPa}$, which was associated with the presence of at least $60 \%$ of E4 stage buds, assured at least $70 \%$ of flowering in arabica coffee. The instantaneous gaseous exchange of coffee plants was strongly affected by the application of water deficit over the short-term; however, no effect was observed on the leaf levels of photosynthetic pigments or the coffee yield. The percentage of cherry fruits increased and that of green fruits decreased with an increase in the water deficit level applied during the pre-flowering of coffee plants.

\section{ACKNOWLEDGEMENTS}

This work was supported by the "Minas
Gerais Research Foundation" FAPEMIG (grant FORTIS-TCT-10254/2014 and CAG-APQ-0032809).

\section{REFERENCES}

ALVIM, P. T. Moisture stress as a requirement for flowering of coffee. Science, 132:354354, 1960.

APARECIDO, E. O.; ROLIM, G. S. Forecasting of the annual yield of Arabic coffee using water deficiency. Pesquisa Agropecuária Brasileira, 53: 1299-1310, 2018.

BRASIL, COMPANHIA NACIONAL DE ABASTECIMENTO. Acompanhamento da safra brasileira: café: safra 2019 - Primeiro levantamento - janeiro/2019. Brasília: Conab, v.5, n. 1, janeiro 2019. 62 p. Disponível em: https:// www.conab.gov.br/info-agro/safras/cafe/boletim-da- 
safra-de-cafe . Acesso em 22 Jan. 2019.

CAMARGO, M. B. P. The impact of climatic variability and climate change on Arabic coffee crop in Brazil. Bragantia, 69: 239-247, 2010.

CAMAYO-VÉLEZ G. C.; ARCILA-PULGARÍN J. Estudio anatómico y morfológico de la diferenciación y desarrollo de las flores del cafeto Coffea arabica L. variedad Colombia. Cenicafé, 47: 121-139, 1996.

CRISOSTO, C. H.; GRANTZ, D. A.; MEINZER, F. C. Effect of water deficit on flower opening in coffee (Coffea arabica L.). Tree Physiology, 10: 127-139, 1992.

DaMATTA, F. M. et al. Ecophysiology of coffee growth and production. Brazilian Journal of Plant Physiology, 19: 485-510, 2007.

DaMATTA, F. M.; RAMALHO, J. D. C. Impacts of drought and temperature stress on coffee physiology and production: a review. Brazilian Journal of Plant Physiology, 18: 55-81, 2006.

FAGAN, E. B. et al. Efeito do tempo de formação do grão de café (Coffea sp.) na qualidade da bebida. Bioscience Journal, 27: 729-738, 2011.

FERNANDES, A. L. T. et al. A moderna cafeicultura dos cerrados brasileiros. Pesquisa Agropecuária Tropical, 42: 231-240, 2012.

FERNANDES, A. L. T. et al. Viabilidade técnica e econômica da irrigação localizada do cafeeiro, nas condições climáticas do planalto de Araxá, MG. Coffee Science, 11: 346-57, 2016.

GIOMO, G. S.; BORÉM, F. M. Cafés especiais no Brasil: opção pela qualidade. Informe Agropecuário, 32: 7-16, 2011.

GONZÁLEZ-ROBAINA, F; CISNEROS-ZAYAS, E.; MONTILLA, E. The coffee tree (Coffea arabica L.) response to water deficit in different development phases. Revista Ciencias Técnicas Agropecuarias, 26: 4-11, 2017.

GUERRA, A. F.; ROCHA, O. C.; RODRIGUES, G. C. Manejo do cafeeiro irrigado no Cerrado com estresse hídrico controlado. Irrigação \& Tecnologia Moderna, 65: 42-45, 2005.

LEITE JÚNIOR, M. C. R.; FARIA, M. A. Utilização da irrigação no controle do potencial matricial de água no solo e sua influência na produtividade do cafeeiro. Revista da Universidade Vale do Rio Verde, 14: 533-544, 2016.
LIU, X. et al. Impacts of regulated deficit irrigation on yield, quality and water use efficiency of Arabica coffee under different shading levels in dry and hot regions of southwest China. Agricultural Water Management, 204: 292-300, 2018.

MAGAlHÃES, A. C.; ANGELOCCI, L. R. Sudden alteration in water balance associate with flower bud opening in coffee plants. Journal of Horticultural Science, 51: 419-423, 1976.

MASARIRAMBI, M. R.; CHINGWARA, V.; SHONGWE, V. D. The effect of irrigation on synchronization of coffee (Coffea arabica L.) flowering and berry ripening at Chipinge, Zimbabwe. Physics and Chemistry of the Earth, 34: 786-789, 2009.

MATIELLO, J. B. et al. Cultura de café no Brasil: manual de recomendações. Ed. 2015. Varginha, MG: PROCAFE, 2016. 585 p.

MELKE, A.; FETENE, M. Eco-physiological basis of drought stress in coffee (Coffea arabica L.) in Ethiopia. Theoretical and Experimental Plant Physiology, 26: 225-239, 2014.

MERA, A. C. et al. Regimes hídricos e doses de fósforo em cafeeiro. Bragantia, 70: 302-311, 2011.

MESQUITA, C. M. et al. Manual do café: colheita e preparo (Coffea arabica L.). 1. ed. Belo Horizonte, MG: EMATER-MG, 2016. 50 p.

OLIVEIRA, L. F. C.; OLIVEIRA, R. Z.; CASTRO, T. A. P. Comportamento fisiológico de cafeeiros submetidos a diferentes disponibilidades de água no solo. Bioscience Journal, 25: 83-91, 2009.

ORTEGA, A. C.; JESUS, C. M. Território café do Cerrado: transformações na estrutura produtiva e seus impactos sobre o pessoal ocupado. Revista de Economia e Sociologia Rural, 49: 771-800, 2011.

PELOSO, A. F. et al. Limitações fotossintéticas em folhas de cafeeiro arábica promovidas pelo deficit hídrico. Coffee Science, 12: 389-399, 2017.

QUIÑONES, A. J. P. et al. Effects of day length and soil humidity on the flowering of coffee Coffea arabica L. in Colombia. Revista Facultad Nacional de Agronomía Medellín, 64: 5745-5754, 2011.

RENA, A. B.; BARROS, R. S. Aspectos críticos no estudo da floração do café. In: ZAMLOLIM, L.

(Ed.). Efeitos da irrigação sobre a qualidade e produtividade do café. Viçosa, MG: UFV/DFP, 2004. Cap. 3, p. 149-172.

RONCHI, C. P. et al. Growth and photosynthetic 
down-regulation in Coffea arabica in response to restricted root volume. Functional Plant Biology, 33: 1013-1023, 2006.

RONCHI, C. P. et al. Respostas ecofisiológicas de cafeeiros submetidos ao deficit hídrico para concentração da florada no Cerrado mineiro. Pesquisa Agropecuária Brasileira, 50: 24-32, 2015.

SAKAI, E. et al. Coffee productivity and root systems in cultivation schemes with different population arrangements and with and without drip irrigation. Agricultural Water Management, 148: 16-23, 2015.

SCHUCH, U. K.; FUCHIGAMI, L. H.; NAGAO, M. A. Flowering, ethylene production, and ion leakage of coffee in response to water stress and gibberellic acid. Journal of American Society of Horticultural Science, 117: 158-163, 1992.

SILVA, C. A.; TEODORO, R. E. F.; MELO. B. Produtividade e rendimento do cafeeiro submetido a lâminas de irrigação. Pesquisa Agropecuária Brasileira, 43: 387-394, 2008.

SILVA, E. A. et al. Seasonal changes in vegetative growth and photosynthesis in Arabica coffee trees. Field Crops Research, 89: 349-357, 2004.

SILVA, E. A. et al. Influência de déficits hídricos controlados na uniformização do florescimento e produção do cafeeiro em três diferentes condições edafoclimáticas do estado de São Paulo. Bragantia, 68: 493-501, 2009.

SISTEMA DE ANÁLISES ESTATÍSTICAS E GENÉTICAS - SAEG. Versão 9.0. Viçosa, MG: Fundação Arthur Bernardes, 2004.

SOARES, A. R. et al. Irrigação e fisiologia da floração em cafeeiros adultos na região da zona da mata de Minas Gerais. Acta Scientiarum. Agronomy, 27: 117-125, 2005.

SOUZA, J. M. de et al. Interrupção da irrigação e maturação dos frutos de café Conilon. Científica, 42: 170-177, 2014.

TAIZ, L. et al. Fisiologia e desenvolvimento vegetal. 6. ed. Porto Alegre, RS: ARTMED LTDA, 2017. $858 \mathrm{p}$.

VINASCO, D. M. M.; BUILES, V. H. R.; GUERRERO, H. A. C. Comportamiento de accesiones de Coffea arabica sometidas a deficit de humedad del suelo. Cenicafé, 67: 41-54, 2016. 